\title{
Expression Levels of B Cell Receptor (BCR) Signaling Pathway Factors are Associated with Conversion from Clinically Isolated Syndrome to Multiple Sclerosis
}

\author{
B Hücre Reseptör (BHR) Sinyal Yolağı Faktörlerinin Ekspresyon Düzeyleri Klinik \\ İzole Sendromdan Multipl Skleroza Dönüşümle İlişkilidir
}

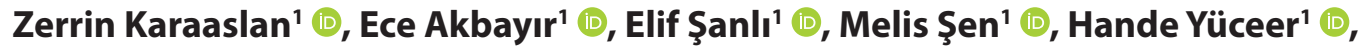 \\ Recai Türkoğlu² (D), Cem İsmail Küçükali' ${ }^{10}$, Erdem Tüzün ${ }^{1}$ (i)
}

'Department of Neuroscience, Aziz Sancar Institute of Experimental Medicine, Istanbul University, Istanbul, Turkey
2Department of Neurology, Haydarpasa Numune Education and Research Hospital, Istanbul, Turkey

ORCID ID: Z.K. 0000-0002-5784-1324; E.A. 0000-0002-8148-6940; E.S. 0000-0002-9593-7394; M.S. 0000-0002-3557-8203; H.Y. 0000-0001-9027-5291; R.T. 0000-0001-7685-4633; C.I.K. 0000-0001-9851-8577; E.T. 0000-0002-4483-0394

Cite this article as: Karaaslan Z, Akbayır E, Şanlı E, Şen M, Yüceer H, Türkoğlu R, Küçükali Cl, Tüzün E. Expression levels of B cell receptor (BCR) signaling pathway factors are associated with conversion from clinically isolated syndrome to multiple sclerosis. Experimed 2021; 11(1): 33-7.

\begin{abstract}
Objective: We have previously shown altered blood B cells in the first attack blood samples of clinically isolated syndrome (CIS) patients, who converted to multiple sclerosis (MS). Our aim was to investigate levels of $B$ cell receptor (BCR)-associated genes expression in converting $\mathrm{CIS}(\mathrm{CIS}-\mathrm{c})$ and non-converting CIS patients (CISnc) with a 5-year follow-up.
\end{abstract}

Methods: Seven CIS-c patients, 12 CIS-nc patients and 10 agesex matched healthy donors were enrolled in this study. RNA was extracted from frozen peripheral blood cells of subjects that were obtained in the first attack using a RNA isolation kit. Expression levels of B-cell adaptor protein with ankyrin repeats 1 (BANK1), B lymphocyte kinase (BLK) and Fc receptor-like protein 2 (FCRL2) genes were evaluated samples by real-time polymerase chain reaction (RT-PCR).

Results: CIS-nc patients showed elevated BANK1, BLK and FCRL2 gene expression levels as compared to CIS-c patients and healthy controls.

Conclusions: Expression levels of the genes that inhibit BCR signaling are increased in CIS-nc, suggesting that inhibiting exaggerated $B$ cell response by optimization of B cell proliferation may prevent the progression of clinically isolated syndrome to MS.

Keywords: Multiple sclerosis, B cell receptor, BANK1, BLK, FCRL2, clinically isolated syndrome
ÖZ

Amaç: Daha önceki çalışmalarımızda, multipl skleroza (MS) dönüşen klinik izole sendrom (KIS) olgularının ilk atakta alınan kan örneklerinde periferik kan B hücre düzeylerinin değiştiğini gösterilmiştir. Bu çalışmada beş yıllık takipte MS'e dönüşen ve dönüşmeyen KiS olgularında B hücre reseptör (BHR) ilişkili genlerin ekspresyon düzeylerinin araştırılması amaçlanmıştır.

Yöntem: Yedi MS'e dönüşen, 12 MS'e dönüşmeyen KiS olgusu ile yaş ve cinsiyet açısından eşleştirilmiş 10 sağlıklı donör çalışmaya dahil edildi. İlk atak döneminde elde edilen donmuş periferik kan mononükleer hücrelerinden (PKMH) RNA izolasyon kiti kullanılarak total RNAlar izole edildi. Örneklerden gerçek zamanlı polimeraz zincir reaksiyonu (RT-PCR) yöntemi ile ankrin tekrarlı B-hücre adaptör proteini (BANK1), B lenfosit kinaz (BLK), Fc reseptör benzeri protein 2 (FCRL2) genlerinin ekspresyonları değerlendirildi.

Bulgular: MS'e dönüşmeyen KIS olgularında BANK1, BLK ve FCRL2 gen ekspresyon düzeyleri MS'e dönüşen KIS olguları ve sağlıklı kontrollere kıyasla artmış olarak saptandı.

Sonuç: BHR sinyalizasyonunu inhibe eden gen ekspresyonlarının MS'e dönüşmeyen olgularda artması, abartılı B hücre yanıtının B hücre proliferasyonunun optimize edilmesi yoluyla baskılanmasının KiS'ten MS'e ilerleyişi engelleyebileceğini düşündürmüştür.

Anahtar Kelimeler: Klinik izole sendrom, multipl skleroz, B hücre reseptörü, BANK1, BLK, FCRL2 


\section{INTRODUCTION}

Multiple sclerosis (MS) is a disabling autoimmune central nervous system disease characterized by myelin loss, axonal degeneration that affects mostly young adults (1). Although it has been long implicated that myelin's antigen specific T cells are the main drivers of MS pathology, recent studies showed that $B$ cells also have crucial roles in the disease mechanism (2).

Due to the presence of meningeal $B$ cell follicles in the brains of patients with the secondary progressive form of MS and the effectiveness of drugs targeting $B$ cells, it is perceptible that abnormal activation of $B$ cells may be a part of MS pathogenesis (3). T cell counts as well as the IFN- $\gamma$ and IL-17 levels are found to be decreased in MS patients after treatment with anti-CD20 monoclonal antibodies, compared to pretreatment levels. This finding suggests that B cells may contribute to MS pathogenesis through an antibody-independent mechanism of action, such as presenting antigens to $T$ cells or regulating cytokine production (4).

Clinically isolated syndrome (CIS) is seen in approximately $85 \%$ of MS patients, and about $60 \%$ of them convert to clinically definitive MS (CDMS) in 20 years (5). B cell counts and levels of B-cell chemo-attractant CXCL13 are increased in the cerebrospinal fluid (CSF) of CIS patients indicating the presence of prominent $B$ cell activation in the early phase of MS (6). In a previous study, we demonstrated that the total B cell counts in the blood samples of CIS patients, who converted to CDMS (CIS-C) were lower compared to non-converting CIS patients (CIS-nc). On the other hand, CIS-nc patients showed reduced frequencies of plasma cells and memory $B$, production of which requires $B$ cell receptor $(B C R)$ signaling pathway activation (7).

We previously showed through transcriptome studies that B cell related genes differently expressed between benign and non-benign MS patients. Bioinformatics analysis and clinical correlations suggested that B lymphocyte kinase (BLK), B-cell adaptor protein with ankyrin repeats 1 (BANK1) and Fc receptor-like protein 2 (FCRL2) expression levels could be related with prognosis (Turkoglu et al., unpublished data). BLK is a tyrosine kinase that plays an important role in early B cell development and interacts with BANK1, an adaptor protein that involves in germinal center formation $(8,9)$. FCRL2 is an immunomodulatory protein that inhibits $B$ cell receptor signals and is expressed in transformed $B$ cells (10). Thus, we selected these genes for evaluation of $B$ cell related factors in conversion from CIS to CDMS.

In this study, our aim was to investigate the significance of $\mathrm{BCR}$ activity in conversion from CIS to MS through comparative measurement of the peripheral blood expression levels of B cell factors that are involved in BCR signaling pathway activation.

\section{MATERIALS AND METHODS}

\section{Subjects}

Twelve CIS-nc patients, who did not convert to CDMS in a fiveyear follow-up, seven CIS-c donors, who converted to CDMS in the same follow-up duration and 10 age-sex matched healthy controls $(\mathrm{HC})$ with no history of prior inflammatory disease were included. CIS was defined as the first demyelinating attack and conversion from CIS to CDMS was determined according to revised McDonald Criteria (11). Patients who received immunosuppressive treatment in the last 3 months or had another coexisting disease, were excluded. Clinical evaluation was performed and the expanded disability status scale (EDSS) scores were determined. Oligoclonal IgG bands (OCB) were evaluated in patient groups.

Patients were followed up every 6 months for five years by the same neurologist and whenever a relapse was suspected

Written informed consent was approved by all participants and the study was approved by Istanbul University, Istanbul Faculty of Medicine, Clinical Research Ethical Committee with the protocol ID of 2012/153937 in 2012.

RNA isolation, CDNA synthesis and real-time polymerase chain reaction (RT-PCR)

Blood samples were collected 4 weeks after the first attack, while patients were not using any medications including immunosuppressive and immunomodulating drugs. Peripheral blood mononuclear cells (PBMCs) were isolated from blood and cryopreserved in storage solution until use (density gradient centrifugation).

The total RNA was extracted from the frozen PBMCs of subjects using a RNA isolation kit (Qiagen, RNeasy Plus Mini Kit, Hilden, Germany) according to the manufacturer's instructions. The cDNA was synthesized by using a SCRIPT cDNA Synthesis Kit (Jena Bioscience, GmbH, Frankfurt, Germany) as per manufacturer's recommendations in $\mathrm{T}_{100^{\mathrm{TM}}}$ Thermal Cycler (Bio-Rad Laboratories, Inc., CA, USA) as followed cycle conditions: 10 minutes at $42^{\circ} \mathrm{C}, 60$ minutes at $50^{\circ} \mathrm{C}$, and 10 minutes at $70^{\circ} \mathrm{C}$. The cDNA samples were diluted as the final concentration would be $200 \mathrm{ng} / \mu \mathrm{l}$.

The RT-PCR assay was performed on a Lightcycler ${ }^{\circledR} 480$ II Instrument (Roche Applied Science, USA) by using LightCycler ${ }^{\circledR}$ 480 SYBR Green I Master. The optimal program of the RT-PCR includes an initial pre-incubation at $95^{\circ} \mathrm{C}$ for 8 minutes, followed by 45 cycles of amplification at $95^{\circ} \mathrm{C}$ for $15 \mathrm{~s}$, primer-dependent ${ }^{\circ} \mathrm{C}(57-63)$ for $60 \mathrm{~s}, 72^{\circ} \mathrm{C}$ for $20 \mathrm{~s}$. A melting step was performed at the end of the amplification using the following cycling parameters: $95^{\circ} \mathrm{C}$ for $5 \mathrm{~s}, 65^{\circ} \mathrm{C}$ for 60 seconds and continuous at $95^{\circ} \mathrm{C}$. Primers designated for BANK1 (F: 5'-GTTCAGACCCCGCACATATT- $3^{\prime}$ and R: 5'-CCTTCCCCTTCCATTTCATT-3'), BLK (F: 5'-TAGATCACAGGGTCGGAAGG-3'and R: 5'-GGCAGCGGATCTTATAGTGC-3'), FCRL2 (F: 5'-CTCTGGGGACTGTTTGGTGT-3' and R: $5^{\prime}$-GGTTGGGCTTGAATAGGTGA-3') and as a housekeeping gene GAPDH (F: 5'-CCATCAATGACCCCTTCATT-3') and R: 5'-TTGACGGTGCCATGGAATTT-3'). The relative mRNA expression 
was measured using the simplified comparative threshold cycle delta, cycle threshold method.

A melting curve analysis was obtained at the end of the cycles and cycle threshold values were calculated from the system software.

\section{Statistical analyses}

SPSS 20 software was utilized for statistical analysis and graphs were performed using GraphPad Prism software. The significance levels of clinical and demographical findings and expression levels of the genes were calculated using the Kruskal-Wallis or Mann-Whitney $U$ tests, as required. Categorical parameters were compared by using the Chi-square test. Correlation analysis was done with Spearman's test.

\section{RESULTS}

\section{Clinical and demographic findings}

There was no difference in EDSS scores, age, or gender among the study groups. Since CIS-nc patients displayed only one attack in 5 years, CIS-c patients had inadvertently significantly higher total and annual number of attacks than CIS-nc patients. Although the prevalence of OCB positivity and the number of MS lesions were statistically comparable, CIS-c patients showed trends towards displaying a higher ratio of OCB positivity and brain lesions. Clinical and demographical characteristics of participants were demonstrated in Table 1.

\section{B cell genes' expression levels}

CIS-nc patients showed trends towards exhibiting elevated expression levels of all three B cell-associated genes. BANK1 expression ( $p=0.074$ ) was significantly higher in CIS-nc patients than $\mathrm{HC}(\mathrm{p}=0.040)$ and showed trend significance compared to CIS-c patients $(p=0.097)$. BLK gene expression levels were significantly higher $(p=0.024)$ in CIS-nc patients in comparison to CIS-c patients $(p=0.013)$ and HC $(p=0.005)$. CIS-nc patients also showed significantly higher $(p=0.018)$ FCRL2 expression levels than $\mathrm{HC}(p=0.003)$ but not CIS-c patients $(p>0.1)$. There were no correlations between gene expression levels and clinical and demographical parameters of CIS-c and CIS-nc patients (data not shown).
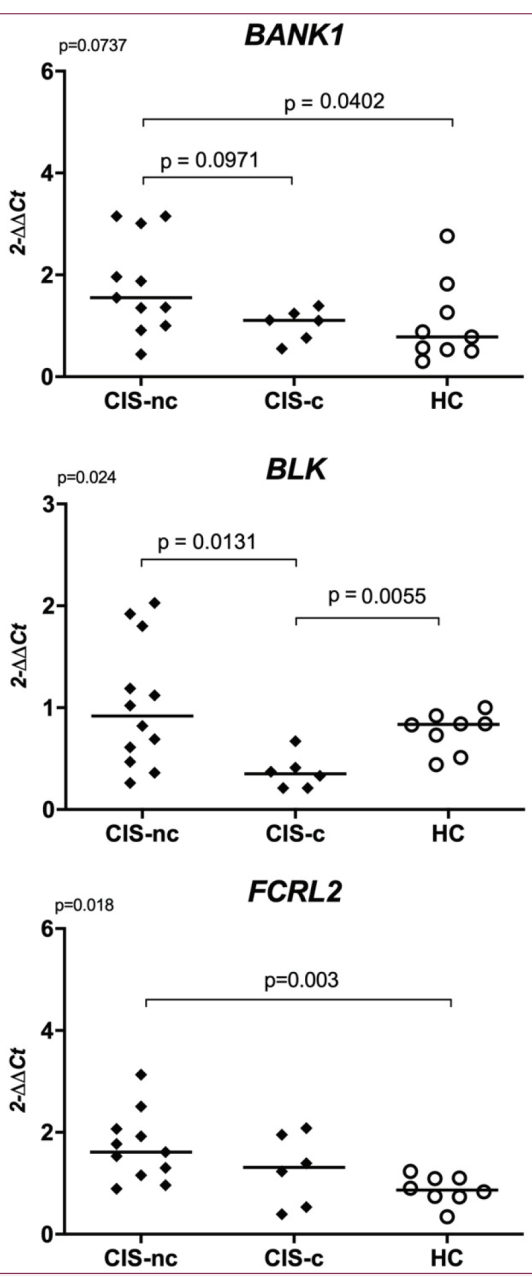

Figure 1. Comparison of relative expression levels of B cell specific genes in study groups. Short horizontal lines indicate mean values. $p$ value on the upper left corner is obtained by Kruskal-Wallis test, whereas $\mathrm{p}$ value over the long horizontal line is obtained by two-group comparisons using MannWhitney $U$ test. CIS-nc: Non-converting clinically isolated syndrome, CIS-c: converting clinically isolated syndrome, HC: Healthy control. Note that only significant $p$ values $(p<0.05)$ and $p$ values with trend significance $(p<0.1)$ were denoted.

Table 1. Clinical and demographical characteristics of healthy controls and CIS patients at the 5th year of follow-up.

\begin{tabular}{|c|c|c|c|c|}
\hline & CIS-nc (n=12) & CIS-c $(n=7)$ & $H C(n=10)$ & p value \\
\hline Gender (Female/Male) & $9 / 4$ & $5 / 2$ & $7 / 3$ & 0.994 \\
\hline Age (mean $\pm S D)$ & $39.83 \pm 3.0$ & $38.14 \pm 2.58$ & $41.70 \pm 4.27$ & 0.315 \\
\hline EDSS (mean \pm SD) & $1.42 \pm 0.56$ & $1.29 \pm 0.27$ & NA & 0.967 \\
\hline Total number of attacks (mean \pm SD) & $1.00 \pm 0.00$ & $2.14 \pm 0.82$ & NA & 0.008 \\
\hline Annual number of attacks (mean \pm SD) & $0.20 \pm 0.00$ & $0.68 \pm 0.44$ & NA & 0.005 \\
\hline OCB (pattern 2 or 3 ) positive/negative & $7 / 5$ & $6 / 1$ & NA & 0.215 \\
\hline Number of MS lesions on MRI & $3.42 \pm 3.75$ & $8.86 \pm 9.26$ & NA & 0.173 \\
\hline
\end{tabular}

CIS-nc: Non-converting clinically isolated syndrome; CIS-c: Converting clinically isolated syndrome; HC: Healthy control; EDSS: Expanded disability status scale scores; 


\section{DISCUSSION}

In our previous study, we showed that the most significant peripheral blood B cell subset differences between CIS-c and CIS-nc were observed in effector B cells (7). In this study, we investigated the expression of the genes, which regulate $B C R$ signaling, and found that CIS patients with increased baseline expression levels of FCRL2, BLK, and BANK1 were less likely to develop CDMS in a five-year follow-up duration. Our results show that peripheral blood expression levels of certain genes may predict prognosis after a single demyelinating attack. To our knowledge, this type of association between these genes and MS has been shown for the first time.

The next question was whether altered expression of these genes prevented MS conversion through suppression of BCR and thus decreased production of effector memory phenotype of B cells and plasma cells. B cell antigen receptor mediated signals are crucial for survival, proliferation, and development of $B$ cells and regulated by activator and inhibitor signals. Defects of BCR signaling can cause a predisposition to autoimmune disorders (12). BANK1 is an adaptor protein recently found to be related to the $B C R$-associated calcium homeostasis and is expressed in immature, mature, and marginal zone B cells but could not be detected in $\mathrm{CD}^{+} \mathrm{T}$ cells, dendritic cells, and macrophages (9). It has been shown that BANK1 attenuates CD40 mediated $B$ cell activation thereby preventing exaggerated $B$ cell responses (13).

Phosphorylation of BANK1 protein after BCR stimulation is provided by its interaction with phospholipase $C$ gamma 2 and BLK, a kinase belonging to the Scr family and primarily expressed in B cells and thymocytes $(14,15)$. Although the role of the BLK protein in humans has not been fully elucidated, its association with autoinflammatory/autoimmune diseases such as systemic lupus erythematosus (SLE) and rheumatoid arthritis (RA) suggests that alteration in BLK expression may cause changes in tolerance mechanisms in B cells (16). Since most of the disease-related BLK haplotypes are correlated with a decrease in BLK expression, lower levels of BLK confer risk for autoimmunity (17).

Another regulator of the BCR signaling pathway is FCRL2, a new member of the immunoglobulin superfamily dominantly expressed by memory B cells, mature B cells, germinal center B cells; slightly expressed in immature bone marrow and plasma cells and contributes to the autoimmune pathogenesis (18). It has been shown to suppress the BCR signaling through the activation of "Src homology region 2 domain-containing phosphatase-1" (SHP-1) (19). Mutations in the FCRL2 genes were found to be associated with SLE, insulin-dependent diabetes, and have indicated an immunomodulatory role of FCRL2 (20). Consistent with our findings, FCRL was found to be downregulated in PBMCs of MS patients with high neurodegeneration signs on magnetic resonance imaging (MRI) (21). In view of these findings, our results imply that a compensatory increase of BANK1, BLK and FCRL2 expressions might be inhibiting BCR signals and thus preventing conversion of CIS to CDMS through suppression of exaggerated $B$ cell responses.

Among the limitations of the study, we could not isolate B cells from peripheral blood due to the amount of the blood samples from patients, since our B cell immunophenotyping results were not different in terms of B cell ratios between patients and healthy subjects $(11.87 \%$ for CIS vs. $8.37 \%$ for RRMS vs. 8.37 for HC) (7), we evaluated gene expressions in PBMC samples by RT-PCR. The other limitation of our study was a low sample size due to the drop-out of patients who did not regularly attempt follow-up visits.

\section{CONCLUSION}

Our findings suggest that B cells may play an essential function in the conversion of CIS to CDMS, and the increase in the expression of $B$ cell regulating genes might prevent this conversion. Meanwhile, evaluating the expression of these genes for the disease in isolated $B$ cells could provide a more specific inference. Also, investigation of potential genetic variants of these genes in MS is warranted. BCR inhibition might be a potential therapeutic target to prevent CIS-MS conversion.

Ethics Committee Approval: The study was approved by the Istanbul Faculty of Medicine Clinical Research Ethical Committee with the protocol ID of 2012/153937.

Peer-review: Externally peer-reviewed.

Author Contributions: Concept - E.T., R.T., C.I.K., E.T.; Data Collection R.T., C.I.K.; Data analysis and/or Interpretation - Z.K., E.A., E.Ş., M.Ş., H.Y.; Literature Search - Z.K., C.I.K.; Writing - Z.K.

Conflict of Interest: The authors have no conflict of interest to declare.

Financial Disclosure: This work was funded by Istanbul University Scientific Research Project Unit. Project number: BAP-2019K12-149071.

Etik Komite Onayı: Çalışma 2012/153937 protokol numarası ile İstanbul Tıp Fakültesi Klinik Araştırmalar Etik Kurulu tarafından onaylanmıştır.

Hakem Değerlendirmesi: Dış bağımsız.

Yazar Katkıları: Çalışma Konsepti - E.T., R.T., C.I.K., E.T.; Veri Toplama R.T., C.I.K.; Veri Analizi/Yorumlama - Z.K., E.A., E.Ş., M.Ş., H.Y.; Literatür taraması - Z.K., C.I.K.; Yazma - Z.K.

Çıkar Çatışması: Yazarlar çıkar çatışması bildirmemişlerdir.

Finansal Destek: Bu çalışma İstanbul Üniversitesi Bilimsel Araştırma Proje Birimi tarafından finanse edilmiştir. Proje numarası: BAP2019K12-149071.

\section{REFERENCES}

1. Noseworthy JH, Lucchinetti C, Rodriguez M, Weinshenker BG. Multiple sclerosis. N Engl J Med 2000; 343(13): 938-52. [CrossRef]

2. Yadav SK, Mindur JE, Ito K, Dhib-Jalbut S. Advances in the im- 
munopathogenesis of multiple sclerosis. Curr Opin Neurol 2015; 28(3): 206-19. [CrossRef]

3. Serafini B, Rosicarelli B, Magliozzi R, Stigliano E, Aloisi F. Detection of ectopic B-cell follicles with germinal centers in the meninges of patients with secondary progressive multiple sclerosis. Brain Pathol 2004; 14(2): 164-74. [CrossRef]

4. Bar-Or A, Fawaz L, Fan B, Darlington PJ, Rieger A, Ghorayeb C, et al. Abnormal B-cell cytokine responses a trigger of T-cell-mediated disease in MS? Ann Neurol 2010; 67(4): 452-61. [CrossRef]

5. Fisniku LK, Brex PA, Altmann DR, Miszkiel KA, Benton CE, Lanyon R, et al. Disability and T2 MRI lesions: a 20-year follow-up of patients with relapse onset of multiple sclerosis. Brain 2008; 131(Pt 3): 80817. [CrossRef]

6. Brettschneider J, Czerwoniak A, Senel M, Fang L, Kassubek J, Pinkhardt E, et al. The chemokine CXCL13 is a prognostic marker in clinically isolated syndrome (CIS). PLoS One 2010; 5(8): e11986. [CrossRef]

7. Aktura SD, Yilmaz V, Ozkan-Yasargun D, Ulusoy C, Tuzun E, Turkoglu R. Peripheral blood memory B cell frequency predicts conversion from clinically isolated syndrome to multiple sclerosis. Mult Scler Relat Disord 2018; 23: 9-14. [CrossRef]

8. Åkerblad $\mathrm{P}$, Sigvardsson M. Early B cell factor is an activator of the $B$ lymphoid kinase promoter in early $B$ cell development. The Journal of Immunology 1999; 163(10): 5453-61.

9. Yokoyama K, Su Ih IH, Tezuka T, Yasuda T, Mikoshiba K, Tarakhovsky $A$, et al. BANK regulates BCR-induced calcium mobilization by promoting tyrosine phosphorylation of IP(3) receptor. EMBO J 2002; 21(1-2): 83-92. [CrossRef]

10. Chikaev NA, Bykova EA, Najakshin AM, Mechetina LV, Volkova OY, Peklo MM, et al. Cloning and characterization of the human FCRL2 gene. Genomics 2005; 85(2): 264-72. [CrossRef]

11. Thompson AJ, Banwell BL, Barkhof F, Carroll WM, Coetzee T, Comi $\mathrm{G}$, et al. Diagnosis of multiple sclerosis: 2017 revisions of the McDonald criteria. Lancet Neurol 2018; 17(2): 162-73. [CrossRef]

12. Gauld SB, Dal Porto JM, Cambier JC. B cell antigen receptor signaling: roles in cell development and disease. Science 2002; 296(5573): 1641-2. [CrossRef]

13. Aiba $Y$, Yamazaki T, Okada $T$, Gotoh $K$, Sanjo $H$, Ogata $M$, et al.
BANK negatively regulates Akt activation and subsequent B cell responses. Immunity 2006; 24(3): 259-68. [CrossRef]

14. Islam KB, Rabbani H, Larsson C, Sanders R, Smith Cl. Molecular cloning, characterization, and chromosomal localization of a human lymphoid tyrosine kinase related to murine Blk. J Immunol 1995; 154(3): 1265-72.

15. Bernal-Quiros M, Wu YY, Alarcon-Riquelme ME, Castillejo-Lopez C. BANK1 and BLK act through phospholipase C gamma 2 in B-cell signaling. PLoS One 2013; 8(3): e59842. [CrossRef]

16. Samuelson EM, Laird RM, Papillion AM, Tatum AH, Princiotta MF, Hayes SM. Reduced B lymphoid kinase (Blk) expression enhances proinflammatory cytokine production and induces nephrosis in C57BL/6-Ipr/lpr mice. PLoS One 2014; 9(3): e92054. [CrossRef]

17. Delgado-Vega AM, Dozmorov MG, Quiros MB, Wu YY, Martinez-Garcia B, Kozyrev SV, et al. Fine mapping and conditional analysis identify a new mutation in the autoimmunity susceptibility gene BLK that leads to reduced half-life of the BLK protein. Ann Rheum Dis 2012; 71(7): 1219-26. [CrossRef]

18. Matesanz-Isabel J, Sintes J, Llinas L, de Salort J, Lazaro A, Engel P. New B-cell CD molecules. Immunol Lett 2011; 134(2): 104-12. [CrossRef]

19. Jackson $T A$, Haga CL, Ehrhardt GR, Davis RS, Cooper MD. FcR-like 2 Inhibition of B cell receptor-mediated activation of B cells. J Immunol 2010; 185(12): 7405-12. [CrossRef]

20. Shabani M, Bayat AA, Jeddi-Tehrani M, Rabbani $H$, Hojjat-Farsangi $M$, Ulivieri $C$, et al. Ligation of human Fc receptor like-2 by monoclonal antibodies down-regulates B-cell receptor-mediated signalling. Immunology 2014; 143(3): 341-53. [CrossRef]

21. Comabella M, Canto E, Nurtdinov R, Rio J, Villar LM, Picon C, et al. MRI phenotypes with high neurodegeneration are associated with peripheral blood B-cell changes. Hum Mol Genet 2016; 25(2): 308-16. [CrossRef] 